\title{
Sexual Experiences of Military Conscripts at the End of the 1990s
}

OSMO KONTULA, Ph.D.

Senior researcher

The Population Research Institute

VESA JORMANAINEN, MD, MSc

Administrative Physician

Defence Staff, Health Care Division

ANNELI MIETTINEN

Researcher

The Population Research Institute

\section{Abstract}

The sexual socialization and sexual experiences of young men past their adolescence have been studied relatively little thus far. In the present study, the subject was approached through surveys conducted in 1996 and 1998 in a number of garrisons. There were 984 male respondents in 1996 and 1220 in 1998, 20 years old on average. Both years, the response rate consisted of 98 percent of the conscripts selected for the study. The themes of the study were the sexual experience, number of partners and use of condoms among young men, and how these relate to the men's habits and values in general.

Seventy-six percent of the men had engaged in sexual intercourse. One out of two had only one partner over the last year, and one out of four had more than one. For one out of three men, the most recent sexual intercourse occurred with a non-steady partner. Less than half of the men used a condom in their most recent sexual intercourse. The age for initiation into sexual intercourse and the number of partners were strongly correlated with whether the conscripts had secondary education and their use of intoxicants. Those who used more intoxicants, started engaging in sexual intercourse at a younger age and engaged into more relationships. Young men had steady relationships and acquired sexual experiences in accordance with their social skills and the choices they had made regarding their career.

Keywords: sexual behavior, sexual partners, condoms, conscripts, intoxicants, habits, Finland 


\section{Introduction}

Sexual issues among young people have been studied relatively extensively in Finland after the mid-1980s. The studies began at the Department of Public Health at the University of Helsinki as the "KISS project" (KISS = maturing, personal relationships, dating and sexuality, transl.). School surveys in numerous localities were used to study young people's sexual experiences, attitudes and use of contraception between the ages of 13 and 17 in 1986, 1988 and 1992 (Kontula 1987; Kontula and Meriläinen 1988; Kontula 1991; Kosunen 1993), and personal interviews were conducted (Tirkkonen, Hukkila and Kontula 1989).

The $\mathrm{WHO}^{1}$ study on school children was launched in the early 1990s by the University of Jyväskylä's Department of Health Sciences. The study looks into the health habits, sexual behavior and contraceptive use of young people, among others. The material was gathered from schools throughout Finland in 1990, 1994 and 1998 (Pötsönen et al. 1993, Pötsönen 1998, Pötsönen and Kontula 1999a). The project includes group interviews of young people (Pötsönen and Välimaa 1995; Pötsönen and Kontula 1999b).

After the mid-1990s Stakes (National Research and Development Centre for Welfare and Health) began an extensive and regionally representative school health study, which examines young people's sexual experiences among other topics. Within the framework of the project, a large number of regional reports have been published in addition to nationally relevant data (e.g. Kosunen et al. 1998; Liinamo et al. 1999).

Compared to the above-mentioned youth studies, a more far-reaching perspective on the initiation phase of young people's sexual life was provided by the FINSEX study of 1992 (Kontula and Haavio-Mannila 1993), which examined sexual issues among the adult population, in part retroactively. The findings could then be compared with similar data from the beginning of the 1970s (Sievers et al. 1974). Follow-up data for the study were gathered for 1999 (Haavio-Mannila, Kontula, Kuusi 2000). The quantitative results of the FINSEX study have also been compared to similar data gathered from twelve other Western European countries (Bozon and Kontula 1998). In Finland, the quantitative data have been supplemented in part by stories included in the sexual autobiographies of people of different generations, about the first unions and sexual experiences in their youth (Kontula and Haavio-Mannila 1995).

Despite the above research, data on the sexual socialization and development of young men past the age of puberty has been rather limited. The FINSEX study (Kontula and Haavio-Mannila 1993) is the only survey to shed light on this topic. However, even in that study, only 159 of the respondents were in the 18-24 age group. The small number of respondents did not permit making generalizations about different sub-groups among young men, or the regional distribution of experiences. 
The young men's voice got heard only in a recently completed study which was based on personal, qualitative interviews (Papp, Kontula and Kosonen 2000). The study focused on 20-24-year-old men and women in the Helsinki metropolitan area, and its objective was to determine the sexual risks taken by the interviewees. Nonetheless, even this study did not permit making generalizations about the sexual development of young men.

A natural solution to studying sexual issues among young men are the periodically conducted survey studies that map out health behavior among conscripts in garrisons located in various parts of Finland. Because the studies are part of military service, they provide a representative sampling of men in this age group, even from a regional perspective.

This article will utilize the conscript surveys conducted in 1996 and 1998 to examine the sexual experience, sexual partners and condom use among young men who are completing their military service. The connection of intoxicants to sexual experiences and condom use will also be examined on the part of the year that preceded military service.

\section{Material and methods}

We carried out two independent cross-sectional questionnaire studies among conscripts in the Finnish Defense Forces (FDF) that followed closely the design and sampling of previously conducted surveys (Jormanainen, Seppälä and Sahi 1997). The conscripts entered common military service in July 1996 or 1998. In 1996, we carefully chose 10 military units (e.g. garrisons), whose catchment areas most likely covered most of Finland, and that did not have special entry criteria. The same garrisons were used also in 1998 .

In each garrison, we used an alphabetically ordered list to sample the first 100 in 1996 and the first 125 in 1998 of those born in January-April. In case there were less names listed than the number requested, sampling was extended to those born in May.

A conscript in our sample independently and anonymously filled out a structured questionnaire in a specially arranged event where he was left in peace but was under surveillance by an FDF military health care staff member. The respondent enclosed the questionnaire in a separate envelope, and envelopes were further sent (unopened) through the mail to the Division of Health Care at the Defense Staff in Helsinki. This was done in 1996 and 1998. 
In 1996, the survey contained the following sexual-related questions:

Have you engaged in sexual intercourse?

How old were you when you first had sexual intercourse?

How many partners (persons) have you had sexual intercourse with?

Have you ever used a condom?

Why did you use a condom for sexual intercourse?

In 1998, in addition to the above, the following questions were added:

How many persons have you had intercourse with in the last year (12 months)?

Who was your most recent sexual partner?

Did you use a condom for your last sexual intercourse?

In 1996, we obtained 984 (98\% of all) responses, whereas in 1998 there were 1,220 $(98 \%)$. The mean age of the respondents was 19.7 years in 1998 (19.6 years in 1996). In both study years, $85 \%$ of the respondents were 18 - 20 -year-olds.

We used Epi Info for data entry and descriptive analyses and SPSS-PC + for crosstabulations.

\section{Findings}

\section{Experience in sexual intercourse and age at initiation}

In 1996, $77 \%$ of the conscripts had engaged in sexual intercourse at least once prior to the study. In 1998, the same number was $76 \%$. There was no change, then, in experience. In 1998 the respondents also included 18 women. Of the women, $83 \%$ had engaged in sexual intercourse.

The young male respondents were at an age where experience increases fairly quickly with age. Both times, in fact, the 20-year-olds were more experienced than the 18- or 19-year-olds (Table 1). Those 21 and over had the most experience. It is worth noting that even among them, $15 \%$ had not experienced sexual intercourse yet.

Initiation age corresponds very well with previous findings in studies on young people. In 1996, $22 \%$ and in 1998, $24 \%$ reported that they first engaged in sexual intercourse before turning 16. The proportion of those who experienced it before the age of 18 was, respectively, $56 \%$ and $57 \%$. Among conscripts who entered military service at a younger age, the experiences had occurred on average at a somewhat younger age compared with those who entered the service later. 
Table 1. Conscripts who experienced sexual intercourse and condom use in 1996 and $1998, \%$

\begin{tabular}{lccrccrr} 
Age of & \multicolumn{3}{c}{1996} & \multicolumn{3}{c}{1998} \\
respondent & Intercourse & Condom & $(\mathbf{N})$ & Intercourse & Condom & (N) \\
18 & 73 & 64 & $(71)$ & 77 & 72 & $(64)$ \\
19 & 73 & 68 & $(446)$ & 70 & 65 & $(551)$ \\
20 & 79 & 73 & $(343)$ & 83 & 78 & $(401)$ \\
$21-$ & 87 & 81 & $(87)$ & 84 & 78 & $(133)$ \\
Total & 77 & 71 & $(960)$ & 76 & 71 & $(1149)$
\end{tabular}

Religion used to have a significant impact on initiation age. A Christian set of values connected intercourse with marriage. Secularization and values emphasizing the individual's rights have since surpassed the importance of religion almost completely. Instead of religion, choices that have to do with education and career are important factors in shaping a person's way of life. They also explain differences in the age at first sexual intercourse. This has been observed in European population-wide sex studies (Bozon and Kontula 1998) and in analyses about young people in Finland (Kontula 1991).

Even among the conscripts, initiation age varied greatly depending on the level of education $^{2}$ attained at that age (Table 2). If the young men had completed high school or had already begun university-level studies, the first time they experienced sexual intercourse was clearly later than for others. Correspondingly, men who had only finished comprehensive school were younger than others when they first engaged in sexual intercourse.

Table 2. Age upon having sexual intercourse for the first time according to the men's level of education, 1996 and 1998 combined, \%

$\begin{array}{lcccccc}\quad \text { Education } & \mathbf{- 1 5} & \mathbf{1 6 - 1 7} & \mathbf{1 8}- & \text { No experience } & \% & \text { (N) } \\ \text { Comprehensive school } & 43 & 34 & 12 & 11 & 100 & (165) \\ \text { Vocational school } & 31 & 36 & 14 & 19 & 100 & (634) \\ \text { Institute } & 19 & 34 & 27 & 20 & 100 & (221) \\ \text { High school+others } & 17 & 33 & 22 & 28 & 100 & (950) \\ \text { University level } & 15 & 24 & 31 & 30 & 100 & (197) \\ \text { Total } & 23 & 33 & 20 & 24 & 100 & (2167)\end{array}$

\footnotetext{
${ }^{2}$ Conscripts are at an age where they are still in the middle of their occupational training or education, and many will go through retraining later. The rapid change can also be seen in the fact that when asked for their education, $47 \%$ of the 18 -year-olds said they were in a trade and technical school, $48 \%$ of the $19-20$-year-olds were in high school, and of those 21 and over, $53 \%$ studied in a college, institute or university-level institution.
} 
Of course, education does not determine sexual life. This was apparent in that one out of ten of those who had only finished comprehensive school had not engaged in sexual intercourse by the time they reached conscription age, and, conversely, $15 \%$ of university students had experienced sexual intercourse for the first time already before the age of 16 . There are a fair number of exceptions, then, to statistical differences.

Educational attainment represents a significant and relatively easy-to-measure component in the basic values of young men. Together with other values and objectives that are closely related to it, it creates an outline and guide for their life and choices. Vigorous studying frequently becomes a way of life, in which love relationships and the use of intoxicants become a part of life only later. When they eventually become current, interest in them tends to be weaker than among contemporaries.

The importance of a way of life becomes concrete when comparing the age when smoking becomes daily habit for men to the age they start engaging in sexual intercourse. A comparison shows that the younger the men were when they started smoking, the younger they also were when they started engaging in sexual intercourse (Table 3). On the other hand, the men who never started smoking on a daily basis had the least sexual experience. One-third of non-smoking men had not experienced sexual intercourse yet. The difference in this respect was three- to four-fold compared with men who smoked.

Table 3. The connection between the age of commencing cigarette smoking and sexual initiation age, 1996 and 1998 combined, \%

\begin{tabular}{lcccccc}
$\begin{array}{l}\text { Age when commenced } \\
\text { smoking }\end{array}$ & \multicolumn{7}{c}{ Sexual initiation age } & & & \\
& -15 & $\mathbf{1 6 - 1 7}$ & $\mathbf{1 8}-$ & No experience & $\%$ & (N) \\
-14 & 56 & 27 & 9 & 8 & 100 & $(316)$ \\
$15-16$ & 35 & 43 & 12 & 10 & 100 & $(403)$ \\
$17-$ & 25 & 40 & 25 & 10 & 100 & $(174)$ \\
Never & 11 & 31 & 24 & 34 & 100 & $(1284)$ \\
Total & 23 & 33 & 20 & 24 & 100 & $(2177)$
\end{tabular}

On average, the men started smoking at a slightly younger age than they began to engage in sexual intercourse. Only one-fifth of the daily smokers had started having intercourse at the same age as they began to smoke (less than one-tenth of all conscripts). $55 \%$ of the men who started smoking before the age of 15 had intercourse by the time they were 16 . This proportion was five times higher than among non-smoking men. 
Young people frequently become interested in intoxicants (including cigarette smoking and experimenting with narcotics) at around the same age as they become interested in sexual experiences. Often, too, the experiences and the use of intoxicants are a kind of gateway to entering a desired group of friends. The significance of this issue for later life could be seen, for example, in that the initiation was connected to how eagerly the conscripts had drunk alcohol to become intoxicated before the interview.

Out of the men who first engaged in sexual intercourse before the age of $16,62 \%$ had drunk themselves to intoxication at least once every month during the last year. Those who had sexual intercourse for the first time at the age of 18 or over, this proportion was $41 \%$, and for those who had not had intercourse yet, it was $25 \%$. According to the inexperienced men themselves, $44 \%$ had not drunk themselves to intoxication at all. In this respect, the difference was five-fold compared to those who began engaging in sexual intercourse at a young age.

The sexual initiation age was also connected to the interest the young men had towards experimenting with narcotics. Of those who began to have sexual intercourse before the age of $16,36 \%$ had tried narcotics (usually cannabis), and the proportion of those who had experimented with narcotics during the last year was $21 \%$. These proportions were six times higher than among those who had not experienced sexual intercourse yet $(6 \%$ and $4 \%$ ).

\section{Sexual partners}

Nearly one-fourth of the men had not had a sexual partner yet at the time of the study, a $45 \%$ of them had had at most one partner. On the other hand, one in four had already had a minimum of five sexual partners. For men 21 and over, this proportion was approximately one-third. Measured by the number of partners, the more plentiful sexual experiences were concentrated on a relatively small group of men.

The more years had passed from sexual initiation, the more partners they had naturally had time to engage in sexual intercourse with (Table 4). Two out of three of the men who began to have sexual intercourse before the age of 16 had already had at least five partners. Conversely, for approximately one-tenth of the men who started this young, the first partner was so far also the only partner.

Of the men who began engaging in sexual intercourse at 18 or later ( $43 \%$ of those who had experienced sexual intercourse), nearly two out of three had only had this first (one) partner. These men, then, had typically settled into a relationship with their first partner. On the other hand, the age at first sexual intercourse was not significantly connected to whether the latest sexual intercourse experience had occurred with a steady partner. 
Table 4. Number of sexual partners in life according to age at sexual initiation, 1996 and 1998 combined, \%

\begin{tabular}{lrrrrrr} 
Initiation age & \multicolumn{7}{c}{ Sexual partners } \\
& $\mathbf{1}$ & $\mathbf{2}$ & $\mathbf{3 - 4}$ & $\mathbf{5 -}$ & $\%$ & (N) \\
-15 & 8 & 8 & 20 & 64 & 100 & $(503)$ \\
$16-17$ & 23 & 21 & 29 & 27 & 100 & $(719)$ \\
$18-$ & 61 & 17 & 14 & 8 & 100 & $(435)$ \\
Total & 28 & 16 & 22 & 34 & 100 & $(1657)$
\end{tabular}

Men who were younger than others when they first had sexual intercourse had had more partners in the last year than average. Half of all men who experienced intercourse for the first time before the age of 16, had at least two partners during the last year. The proportion was only one-fifth for those who started having sexual intercourse at age 18 or later.

In 1998 , nearly one out of two men ( $48 \%$ ) had a spouse or steady sexual partner at the time of the survey. If this proportion is calculated for those who had experienced sexual intercourse, $62 \%$ had a steady partner and $15 \%$ had a marital or consensual partner. This corresponds to two men out of three stating that they last engaged in intercourse with a steady partner. On the other hand, $30 \%$ of all conscripts (and $38 \%$ of those who had experienced intercourse) last had sexual intercourse with a non-steady partner ${ }^{3}$.

Of those who entered "unmarried" as their marital status (not engaged or in a consensual union), one out of two last had intercourse with a steady partner, and $45 \%$ had it with a free and previously unknown partner.

Some of the men were monogamous, that is, lived according to the monogamous ideal. Out of the men who were in a steady relationship at the time of the survey, one out of three had so far only had one partner. Fifteen percent of all men belonged to the group of men who had had only one steady partner, in other words, had had no other partners or temporary partners.

The ways in which alcohol was used in the year prior to the study was considerably related to what kind of partner the men last had intercourse with. Of the men who in the last year consumed alcohol to the point of an advanced state of intoxication no more than a few times, over one-fourth last had intercourse with a non-steady partner. For those who drank themselves to intoxication every week, the figure was significantly higher, $58 \%$. 
In 1998, the conscripts were asked to give the number of sexual partners in the last year. Based on the 1998 information, $72 \%$ of all men had at least one sexual partner (that is, they had had intercourse during that year). Nearly one out of two (45\%) had only one partner. One in four $(27 \%)$ had more than one partner. One-third of the men who had experienced intercourse had two or more partners during the year. Fourteen percent of all men and $18 \%$ of those who had experienced intercourse before had had three or more partners. The proportion of young men who changed sexual partners, then, was fairly small.

Using alcohol to become intoxicated was clearly connected to whether a man had had more than one sexual partner in the last year (Table 5). Only $7 \%$ of men who refrained from using alcohol to become intoxicated had more than one sexual partner in the last year, and one out of two had no partner. On the other hand, more than one out of two of the men who drank to become intoxicated on a weekly basis had multiple partners. One-third of those who drank to become intoxicated on a weekly basis had had at least three partners during the last year.

Table 5. Number of sexual partners in the last 12 months, according to frequency of drinking to become intoxicated, smoking and experimenting with drugs in $1998, \%$

\section{Sexual partners in last 12 months}

\begin{tabular}{lcrrrrrr} 
Drinking to become intoxicated & \multicolumn{1}{c}{$\mathbf{0}$} & $\mathbf{1}$ & $\mathbf{2}$ & $\mathbf{3 - 4}$ & $\mathbf{5}-$ & $\mathbf{\%}$ & $\mathbf{N}$ \\
- a maximum of once a year & 55 & 38 & 4 & 2 & 1 & $(100)$ & $(250)$ \\
- 3-6 times/year & 27 & 52 & 11 & 6 & 4 & $(100)$ & $(398)$ \\
- -12-24 times/year & 19 & 47 & 18 & 9 & 7 & $(100)$ & $(413)$ \\
- every week & 10 & 32 & 23 & 17 & 18 & $(100)$ & $(130)$ \\
Total & 28 & 46 & 13 & 7 & 6 & $(100)$ & $(1191)$ \\
Smoking & & & & & & & \\
- not at all & 40 & 42 & 10 & 4 & 4 & $(100)$ & $(608)$ \\
- occasionally & 22 & 51 & 12 & 9 & 6 & $(100)$ & $(190)$ \\
- regularly & 11 & 48 & 19 & 12 & 10 & $(100)$ & $(366)$ \\
Total & 28 & 45 & 13 & 8 & 6 & $(100)$ & $(1164)$ \\
Experimenting with drugs & & & & & & & \\
- - never & 32 & 47 & 11 & 5 & 5 & $(100)$ & $(963)$ \\
- over a year ago & 12 & 47 & 18 & 14 & 9 & $(100)$ & $(108)$ \\
- in last 12 months & 11 & 39 & 21 & 18 & 11 & $(100)$ & $(116)$ \\
Total & 28 & 46 & 13 & 7 & 6 & $(100)$ & $(1187)$ \\
& & & & & & &
\end{tabular}

The connection between smoking cigarettes and the number of sexual partners in the last year was also notable, but less significant than the connection between drinking to intoxication and number of sexual partners. Of the non-smokers, $18 \%$ had had two or more partners, whereas this proportion among regular smokers was double, $41 \%$. There was a four-fold difference $(40 \% / 11 \%)$ in the proportion of those who had had no partners, in accordance with smoking habits. 
The connections between experimenting with drugs and the number of sexual partners in the last year were also important, and on a similar level with smoking. Nearly one out of two of those who had tried drugs at some point had had multiple partners, and onefourth had had at least three partners. It did not make much difference whether experimenting with drugs was recent or had occurred several years before. The difference compared to those who had never tried drugs was two- to three-fold.

The latter connection was not created by effects of drug use itself, rather, the men were divided according to whether they had ever been interested in experimenting with drugs in the first place. Those who were interested in drugs were also more likely than average to be interested in multiple sexual partners, or they had had more opportunities and ability than others to form such relations.

The above-observed connections, between drinking to be intoxicated, cigarette smoking, drug experimentation and the number of sexual partners, were the same for 1996 and 1998.

\section{Condom use}

In both study years, $71 \%$ of all men had used a condom at least at some point before entering military service. On the other hand, approximately one-fifth of all those 21 and over had never used a condom. According to the men who had engaged in sexual intercourse, a total of $7 \%$ had never used a condom.

In 1998 (not included as a question in 1996), $45 \%$ of the men indicated they used a condom the last time they had intercourse. This proportion among 18-19-year-olds was approximately half and among 20 -year-olds it was $43 \%$. Of men over 20 , only $32 \%$ had used a condom the last time they had intercourse. The differences have to do with relationships becoming more established, with the accompanied increase in use of birth control pills. One out of two men who began to have sexual intercourse at 16 or later had used a condom, but of the men who began under 16 , only one-third ( $35 \%)$ had used condoms.

Regardless of the number of previous partners, approximately one out of two men used a condom the last time they engaged in sexual intercourse. The only exceptions were the men who had had at least five partners up to that point. Of them, only $38 \%$ used a condom the last time they had intercourse. This was mainly due because they had a steady partner who used birth control pills.

When the men were asked for reasons for using a condom in their last sexual intercourse (they were allowed to provide multiple reasons), $80 \%$ named preventing unwanted pregnancy. It made no difference in the case of this justification whether the 
last partner was steady or temporary. $60 \%$ justified the use of a condom by saying it provided protection against venereal disease. Of the men who last engaged in intercourse with a partner previously unknown to them, $80 \%$ used this explanation.

Thirty percent of the men explained condom use by saying that they did not know their partner well enough. Of the men who last had intercourse with an unknown partner, 70 $\%$ used this explanation. Twenty percent explained their condom use by stating that the partner wanted to use one. If the last sexual partner of a man had been the spouse of another man, one out of two respondents gave this explanation.

Young men's condom use was greatly influenced by whether they had a marital or other steady partner. Of men who were in steady relationships only $33 \%$ (with a spouse, $29 \%$ ) had used a condom the last time they had intercourse. Of the men who last had intercourse with a non-steady partner, $65 \%$ had used a condom. Thus, third of the men had had unprotected sex with their last non-steady partner. One out of two men who had last had intercourse with the spouse of another man had used a condom.

The number of sexual relationships in the last year had no particular connection to condom use in the last act of intercourse. Among men who had had more than one partner that year, one out of two had used a condom the last time they had sexual intercourse.

Condom use was more rare among men who drank to become intoxicated more frequently than others. Of the men who abstained altogether from drinking to become intoxicated, $55 \%$ used a condom the last time they had sexual intercourse. Among men who drank to become intoxicated every week, this figure was only $36 \%$. Among nonsmoking men $52 \%$ used a condom the last time they had sexual intercourse, and the figure among smokers was $43 \%$.

\section{Regional differences}

As a result of the increased mobility that accompanies a more effective mass media, rapid growth in school sizes and the proliferation of cars, youth and sexual culture have become fundamentally more uniform. The significance of a young person's place of residence is less and less important in terms of acquiring sexual information, forming attitudes or even acquiring sexual experiences. However, the environment will have an impact on the extent to which a young person has practical opportunities or options to find a sexual partner he/she is interested in and who in turn is willing to be that partner.

To determine possible regional differences, the men's sexual experience, number of sexual partners, and condom use were originally examined along the old province lines. The differences thus discovered did not seem remarkable or systematic. In what follows, only the findings that deviated significantly from the mean is presented. 
In terms of experience (if the man had ever engaged in sexual intercourse), the Turku and Pori province ( $84 \%$ ) and the Oulu province $(62 \%)$ deviated from the rest ( $76 \%$ in the country as a whole). The percentage of conscripts who had had intercourse with more than one partner in the past year was $32 \%$ in the Turku and Pori province and 20 $\%$ in the provinces of Central Finland and Vaasa ( $27 \%$ in the country as a whole). The lower figures in the provinces of Oulu and Vaasa in experience and number of sexual partners are a result of the religiosity of these regions, which surpasses that of the rest of the country. In use of condoms, only the Mikkeli province deviated to its advantage $-67 \%$ of the men had used a condom the last time they had intercourse ( $45 \%$ in the country as a whole).

This study examines regional differences in sexual experience and condom use mainly in accordance with the number of inhabitants of cities and towns, and the density of population in rural areas. The differences examined thus did not prove very significant, but they were, in fact, consistent with the several indicators used in the study (Table 6).

Table 6. Regional differences connected to sexual experiences and condom use according to the population base of the conscript's place of residence (size of city/density of population in rural areas), 1996 and 1998 combined, $\%$.

$\begin{array}{lccccc}\text { Residence } & \begin{array}{c}\text { No inter- } \\ \text { course yet }\end{array} & \begin{array}{c}\text { Intercourse } \\ \text { before } \mathbf{1 6}\end{array} & \begin{array}{c}\text { Used } \\ \text { condom }\end{array} & \begin{array}{c}\text { 5 or more } \\ \text { partners }\end{array} & \text { (N) } \\ \text { Helsinki metropol. } & 19 & 24 & 77\left(42^{\star}\right) & 30 & (480) \\ \text { City, over 100,000 } & 16 & 31 & 79\left(41^{\star}\right) & 36 & (196) \\ \text { City, 20,000-100,000 } & 22 & 24 & 71\left(50^{*}\right) & 25 & (543) \\ \text { Town, over 20,000 } & 26 & 22 & 69\left(54^{*}\right) & 20 & (297) \\ \text { Rural, dense pop. } & 29 & 22 & 66\left(49^{*}\right) & 22 & (405) \\ \text { Rural, sparse pop. } & 31 & 16 & 64\left(54^{\star}\right) & 20 & (246) \\ \text { Total } & 24 & 23 & 71\left(48^{*}\right) & 25 & (2167)\end{array}$

$\left(^{*}\right)=$ condom use in most recent act of sexual intercourse in 1998

Men started engaging in sexual intercourse at a younger age on average and they had acquired more sexual experiences if they lived in a large city (over 100,000 inhabitants) outside of the capital city, followed by the metropolitan area of the capital city itself. There was no significant change in this between 1996 and 1998. Also, the proportion of men who had engaged into several relationships during the past year was several percentages higher in 1998 in these cities compared to other places of residence. Young men who lived in sparsely populated rural areas had less sexual experiences and started older than others. Differences between other places of residence were very minor. 
Those who lived in large cities had the most experience of condom use. This was mainly a result of a more active sexual life than elsewhere. Men living in large localities had nevertheless used condoms more rarely in their latest intercourse than men living in smaller localities. They had already settled into a steady relationship in which their partners took care of contraception.

The difference between the capital and the rest of the country was illustrated by the fact that $13 \%$ of the men living in the capital area had been to or had an AIDS test. This figure in the rest of the country was $5-7 \%$.

\section{Discussion}

The survey data gathered in 1996 and 1998 was combined in most cases for analysis, because any tabulation used did not reveal significant differences between the two sets of material or the internal relations within the material. Young men's sexual behavior and the relations between that and the rest of their habits and values had not changed in the latter half of the 1990s. Earlier studies, too, have shown that the age of sexual initiation among young men (and women) has been quite stable in the 1980s and 1990s.

Different types of written material (including Kontula and Haavio-Mannila 1995) have shown that it is common among conscripts to brag about repeated conquests of women. On the basis of the information recovered from these surveys, this kind of talk is greatly exaggerated. One out of two men had a steady partner in the last year, and no other partners. One in four had no experience of intercourse at all. Approximately $30 \%$ of the men had still never used a condom. Only $6 \%$ had had five or more sexual partners in the past year.

The study brings more comprehensive information of the large number of young men who have not engaged in sexual intercourse by the age of about 20 . The proportions are several percentages higher than in the FINSEX study (Kontula and Haavio-Mannila 1993; Haavio-Mannila, Kontula and Kuusi 2000). There is a greater variation in the sexual development among young men than there is among young women. Only about one in ten women experiences their first sexual intercourse after reaching 20 (HaavioMannila, Kontula and Kuusi 2000).

Quite a few men were still lacking personal experience in sexual matters, and relatively few men had plentiful experiences. Even among sexually experienced men, the use of condoms was too sporadic, especially with unknown sexual partners. On the basis of this and previous knowledge, the time of the military service would be an excellent opportunity for educating young men on sexual matters and contraception. So far there have been limited campaigns, recently in cooperation with organizations in civil society 
(Heikkilä et al. 1996). The campaigns have aimed to improve the men's awareness of venereal disease and HIV infection, with relatively good results. In a survey conducted following one of the campaigns (Heikkilä et al. 1996), the researchers found that the men's awareness and attitudes toward sexual diseases were on a good level.

The age of sexual initiation reported by the conscripts corresponds particularly well with figures in youth studies of the 1980s and 1990s and with the information provided by people born after the beginning of the 1960s in the FINSEX study. In addition, the age of engaging in sexual intercourse for the first time is close to most Western European countries, with the exception of Southern Europe, where men say they start having sexual intercourse somewhat younger (Bozon and Kontula 1998).

The age of sexual initiation and the number of sexual partners were strongly connected to educational attainment and habits of using intoxicants. These observations support earlier findings (Kontula 1991) that indicate that young people's sexual experiences become part of a broader way of life and reflect their values, and social and life career choices. From a moral perspective it is possible to speak of fine, young people who focus on their studies and future career and exhibit little interest in intoxicants, narcotics or sexual experiences.

From a social perspective, on the other hand, one can talk about young people who are not very socially adept or popular (as a result of weak resources, they are left out of the young people's reference groups what they long for), and as a result are unable to form sexual or love relationships, even though they long for them. Concentrating on their studies may compensate for this lack.

An interpretation made by a person who is on the outside of the young person's way of life (for example, opinions of deviating from a desired way of life) depends on this persons value choices. In making an interpretation, it must be remembered that it may just as well be an issue of choices the young person has chosen to make (life management) as it may be a question of the young person being driven into a situation in which he/she feels it is impossible to guide his/her life into the desired direction.

Although the conscripts have more sexual partners only in certain exceptions, they are in a relatively unsettled phase when their life is looked at as a whole. As an example, for approximately one-third of the men their last sexual intercourse occurred with a nonsteady sexual partner (in most cases previously unknown to them). For those who frequently drank to become intoxicated, this figure was much higher. Among men who are older than the conscripts, the most recent sexual partner was previously unknown to them in only one out of ten cases (Kontula and Haavio-Mannila 1993). 
Youth is a time for searching for the appropriate life partner. The Finnish Defense Forces could be more active than presently in supporting young men in making this search successful. In addition to educating the conscripts on sexual diseases and contraception, their interactive skills should be developed. Improving them would significantly increase the use of condoms and add quality to the men's sexual experiences and their relationships.

\section{References}

Bozon, Michel and Osmo Kontula. 1998. Sexual initiation and gender: A cross-cultural analysis of trends in the 20th century. In: Sexual behaviour and HIV/AIDS in Europe: Comparisons of National Surveys, edited by Michel Hubert, Nathalie Bajos and Theo Sandfort, pp. 37-67. London: UCL Press.

Haavio-Mannila, Elina, Osmo Kontula and Elina Kuusi. 2000. Trends in Sexual Life: Measured by national sex surveys in Finland in 1971, 1992 and 1999 and a comparison to a sex survey in St. Petersburg in 1996. Väestöntutkimuslaitoksen julkaisusarja E9/2000. Väestöliitto. Helsinki. (in press)

Heikkilä, Rami, Vesa Jormanainen, Birgit Eklund, Matti Lehesjoki and Erkki Kallio. 1996. Lounaissuomalaisten nuorten miesten terveyskäyttäytyminen keväällä 1995 (The health behavior of young men in southwestern Finland in Spring 1995). Sotilaslääketieteellinen Aikakauslehti 71:35-42.

Jormanainen, Vesa, Timo Seppälä, and Timo Sahi. 1997. Huumeita kokeilleet varusmiehet kesällä 1996 (Conscripts who experiment with drugs, Summer 1996). Suomen Lääkärilehti 52: 2325-9.

Jormanainen, Vesa, Mattinen, Mika, Lindén, Kari, Seppälä, Timo and Sahi Timo. 2000. Ystäväpiirin, elämäntapojen ja nuorisokulttuurin piirteitä huumeita käyttäneillä varusmiehillä vuonna 1998 (Characteristics in the circle of friends, ways of life and youth culture among drug-using conscripts in 1998). Suomen Lääkärilehti 55: 359-61.

Kontula, Osmo. 1987. Nuorten seksi (Young people's sex). Keuruu: Otava.

Kontula, Osmo and Jouni Meriläinen. 1988. Nuorten kypsyminen seurusteluun ja seksuaalisuuteen (The maturing of young people to dating and sexuality). Lääkintöhallituksen tutkimuksia. Terveyskasvatus, sarja tutkimukset $9 / 1988$. Helsinki: Valtion painatuskeskus.

Kontula, Osmo. 1991. Sukupuolielämän aloittamisen yhteiskunnallisista ehdoista (On the cultural terms of sexual initiation). Sosiaali- ja terveyshallitus. Tutkimuksia 14/1991. Helsinki: Valtion painatuskeskus.

Kontula, Osmo and Elina Haavio-Mannila (eds.). 1993. Suomalainen seksi: Tietoa suomalaisten sukupuolielämän muutoksesta (Finnish sex: Information on the change in sexual life in Finland). Juva: WSOY.

Kontula, Osmo and Elina Haavio-Mannila. 1995. Matkalla intohimoon: Nuoruuden kärsimys ja hurma seksuaalielämäkertojen kuvaamana (On the way to passion: the suffering and joy of youth revealed in sexual autobiographies). Juva: WSOY.

Kosunen, Elise. 1993. Teini-ikäisten raskaudet ja ehkäisy (Teenage pregnancy and contraception). STAKES. Raportteja 99/1993. Jyväskylä: Gummerus. 
Kosunen, Elise, Matti Rimpelä, Arja Liinamo, Jukka Jokela, Andres Vikat and Arja Rimpelä. 1998. Nuorten seksuaalikäyttäytyminen Suomessa 1996-1997 (The sexual behavior of young people in Finland in 1996-1997). Suomen Lääkärilehti 53:30:3353-3360.

Liinamo A., M. Koskinen, P. Terho, M. Rimpelä, E. Kosunen and J. Jokela. 1999. Kouluterveyskyselyt 1996 ja 1998: Seksuaaliopetus ja seurustelukokemukset Turussa (Sexual education and dating experiences in Turku). Turun kaupungin terveydenhuollon julkaisuja N:O 1/1999. Turku.

Papp, Krista, Osmo Kontula and Kati Kosonen. 2000. Nuorten aikuisten seksuaalikäyttäytyminen ja seksuaaliset riskinotot (The sexual behavior and sexual risktaking of young adults). Väestöntutkimuslaitoksen julkaisusarja D 36/2000. Väestöliitto. Helsinki. (in press).

Pötsönen, Riikka, Lasse Kannas and Raija Välimaa. 1993. Teiniseksiä heinäladosta porttikongiin - Sosiaalisen taustan yhteys suomalaisten nuorten biologiseen kypsymiseen ja seksuaaliseen käyttäytymiseen: WHO-koululaistutkimus (Teen sex from the hay stack to the alleyway - the connection between social background and the biological maturity and sexual behavior of Finnish young people: WHO study on school children). Terveyskasvatuksen vuosikirja 1992. Sosiaali- ja terveysministeriön selvityksiä 1993:1. Helsinki: Painatuskeskus Oy.

Pötsönen, Riikka and Raija Välimaa. 1995. Seurustelua ja pelkkää asiaa. 15-vuotiaiden nuorten ajatuksia teemoista: seurustelu, seksi, ehkäisy, tiedonlähteet ja perhesuunnittelupalvelut (Dating and straight talk: relationships, contraception, information sources and family planning services). Terveystieteen laitoksen julkaisusarja 1/95. Jyväskylä: Jyväskylän yliopisto.

Pötsönen, Riikka. 1998. Naiseksi, mieheksi, tietoiseksi: Koululaisten seksuaalinen kokeneisuus, HIV/AIDS-tiedot, -asenteet ja tiedonlähteet (To become a woman, a man, to become aware: the sexual experience, HIV/AIDS knowledge, attitudes and sources of information of school-aged children). Studies in sport, physical education and health 59. Jyväskylän yliopisto. Jyväskylä.

Pötsönen, Riikka and Osmo Kontula. 1999a. How are attitudes towards condoms related to gender and sexual experiences among adolescents in Finland? Health Promotion International 14:3:211-219.

Pötsönen, Riikka and Osmo Kontula. 1999b. Adolescents' knowledge and attitudes concerning HIV infection and HIV infected persons: how a survey and focus group discussions are suited for researching adolescents' HIV/AIDS knowledge and attitudes. Health Education Research 14:4:473-484.

Sievers, Kai, Osmo Koskelainen and Kimmo Leppo. 1974. Suomalaisten sukupuolielämä (Sexual life of Finns). Porvoo: WSOY.

Tirkkonen, Jarko, Kristiina Hukkila and Osmo Kontula. 1989. Tyttöjen ja poikien seksuaalikulttuurit (Girls' and boys' sexual cultures). Lääkintöhallituksen julkaisuja. Terveyden edistäminen, sarja tutkimukset 15/1989. Helsinki: Valtion painatuskeskus. 